\title{
Cakes and Ale, Paintings and Sculptures: Directors' Duties and Corporate Art Collecting
}

\author{
Elizabeth Harris ${ }^{1} \&$ Bede Harris ${ }^{2}$ \\ ${ }^{1}$ BA LLB (Hons) Graduate, Australian National University, Australia \\ ${ }^{2}$ School of Accounting and Finance, Charles Sturt University, Australia \\ Correspondence: Dr Bede Harris, School of Accounting and Finance, Charles Sturt University, P O Box 789, \\ Albury NSW 2640, Australia. E-mail: beharris@csu.edu.au
}

Received: May 4, $2020 \quad$ Accepted: June 11, $2020 \quad$ Online Published: August 30, 2020

doi:10.5539/jpl.v13n3p268 URL: https://doi.org/10.5539/jpl.v13n3p268

\begin{abstract}
Corporations spend significant amounts of money on art collecting and art sponsorship, but little research has been done on the question of whether such activities are permissible in light of directors' duties. This article addresses that issue by examining whether corporate expenditure on art collecting and sponsorship is consistent with the duty to act in the bests interests of a corporation, the duty to exercise powers for a proper purpose and the fiduciary duty not to make improper use corporate information or position. This is done first by examining the scale of corporate expenditure on art and then by analysing the case law on various directors' duties, before discussing whether corporate art collecting is legitimate in light of those duties. The article examines the most important reasons why a corporation may collect art - as an investment, in furtherance of corporate social responsibility goals and in order to enhance the psychological well-being of employees - and concludes that while art collecting for such purposes does not amount to a breach of directors' duties, this is subject to the requirement that a corporation put into place safeguards contained in a formalised art collecting and sponsorship policy, the key principles of which are stated at the end of the article.
\end{abstract}

Keywords: art, Australia, collecting, company, corporate, corporate social responsibility, director, directors' duties, fiduciary, investment

\section{Introduction}

This article examines the relationship between two areas which may on the face of it appear to be unrelated corporate expenditure on art collecting and the duties of directors and officers of corporations. Part 2 discusses the scale and nature of corporate expenditure on collecting, focussing on the shift from executives driving corporate art collecting to the use of corporate curating professionals, and changing attitudes toward acquiring contemporary art for corporate collections. Part 3 discusses the duty of directors and other corporate officers under Australian law to act in the best interests of the corporation and to exercise powers for a proper purpose, and how these duties interact. Part 4 examines the circumstances in which expenditure on art collecting is or is not consistent with directors' duties. Part 5 concludes by outlining general principles which should govern boards in formulating policies relating to expenditure on corporate art collecting.

\section{Corporate Expenditure on the Arts}

One of the first, and most well-know, corporate art collections is the JPMorgan Chase Art Collection. Established in 1959 by David Rockefeller, then President of The Chase Manhattan Bank, the Collection oversees more than 30000 objects in 450 corporate offices around the globe. ${ }^{1}$ The Collection's website notes that 'JPMorgan Chase $\&$ Co. believes that arts and culture are the lifeblood of vibrant communities', and ties the collection to the firm's 'global philanthropic and sponsorship activities.' ${ }^{2}$ But even with its average of 67 pieces per corporate office, the JPMorgan Chase Art Collection is not the largest in the world - this title belongs to corporate art collecting heavyweight, Deutsche Bank. With over 70000 pieces, Deutsche Bank's collection is over double the side of JP

\footnotetext{
1 JPMorgan Chase \& Co. (2020). JPMorgan Chase Art Collection. Retrieved from https://www.jpmorganchase.com/corporate/AboutJPMC/jpmorgan-art-collection.htm

${ }^{2}$ Ibid.
} 
Morgan's. ${ }^{3}$ Then there is UBS' collection; the Swiss Bank has a collection so large that its artwork to employee ratio is $1: 2 .^{4}$

Shifts in how corporations collect art illustrate the impact of directors' duties on art collecting. In decades past, a CEO may have purchased art that appealed to their taste, and then kept it out of sight in their office. Private preference and the whims of directors have been displaced by company-wide strategies. ${ }^{5}$ Art collecting has become less a matter of executive taste, and more embedded in public relations, productivity, and philanthropic strategies. In 1960, David Rockefeller bought Mark Rothko's White Centre (Yellow, Pink and Lavender on Rose) personally for $\$ 8,500$ after the piece was considered too abstract for Chase Manhattan to buy for its corporate collection. The painting was hung in Rockefeller's outer offices for 47 years. ${ }^{6}$. When the painting was sold at Sotheby's in 2007, the opening bid of \$28 million (\$6 million above Rothko's auction record) escalated in two and a half minutes to a $\$ 78.2$ million sale price. ${ }^{7}$ Of the sale, New York dealer Nicholas Maclean said the buyer 'had just bought a Rockefeller'. ${ }^{8}$ However this emphasis on individualism has waned; while in the years prior to the art collecting boom of the 1990 s, $55 \%$ of corporate collections were managed by the chief executive, by 2007 , nearly $30 \%$ of companies had established art collecting departments, or siphoned off art collecting responsibilities to a public relations or marketing department. ${ }^{9}$

Generally speaking, there are two groups which tend to be responsible for corporate art collecting: professional art curators and corporate trained executives. ${ }^{10}$ Professional art curators who work as corporate curators have for the most part wrested the reins of corporate collecting from chief executives. ${ }^{11}$

The Macquarie Group states that its collection is curated by a volunteer committee of Macquarie staff and a curatorial expert. ${ }^{12}$ Curatorial advisor Barbara Flynn, who was engaged by Deloitte to help shape their corporate collection, said in conversation with the ABC that the Big 4 firm uses a panel of graduates, executives and art collecting experts to determine what works are acquired for the corporate collection. Works would be displayed at Deloitte's Sydney office on the visitors' floor, allowing some 6000 people a week to view the show prior to acquisitions being made. ${ }^{13}$ Where the decision is made to allow directors and employees to have prime stewardship over the collection, few corporate employees and officers are trained in operating in the art market this will especially be a concern where companies wish to buy investment grade art. It will then be necessary to obtain the services of art consultants.

When companies collapse, the spotlight is quickly shone on art collections and collecting practices; questions rapidly surfaced regarding Lehman Brothers' corporate art collection after the hedge fund's 2008 collapse. ${ }^{14}$ The collection was auctioned at Sotheby's in 2010 to raise funds for creditors, selling for $\$ 12$ million in total. ${ }^{15}$ CEO Richard Fuld was (after the fact) criticised for his attention to his private art collecting as late as August 2008 (the month in which 1500 Lehman Brothers employees were made redundant), when he arranged a \$20 million auction guarantee from Christies to sell a selection of drawings from his private collection. ${ }^{16}$

Today, many companies pride themselves on the contemporary works they acquire, rather than avoiding the new

\footnotetext{
3 Jovic, M. (2018). Art Owned by Businesses: The Changing Role of Corporate Art Collections. Retrieved from https://medium.com/predict/art-owned-by-businesses-the-changing-role-of-corporate-art-collections-5292e65c9b17

${ }^{4}$ Sooke, A. (2014). Corporate Art Collections: The greatest art you can't see. Retrieved from http://www.bbc.com/culture/story/20140814the-greatest-art-you-cant-see

${ }^{5}$ Behnke, C. (2007). Corporate Art Collecting: A Survey of German-Speaking Companies. The Journal of Arts Management, Law, and Society, $37,225-244,227$.

${ }^{6}$ Thompson, D. (2012). The \$12 Million Stuffed Shark: The Curious Economics of Contemporary Art. London: Quarto, 21-2.

7 Ibid 23.

${ }^{8}$ Ibid 24

9 Behnke, above n 5, 228.

${ }^{10}$ Ibid 227.

11 Ibid 228.

12 Macquarie Group Ltd. (2020). Macquarie Group Collection. Retrieved from https://www.macquarie.com/au/en/about/community/macquarie-group-collection.html

${ }^{13}$ Cathcart, M. (Presenter). (8 December 2015). Corporate Art Collections [Radio series broadcast]. Barraud, A. and Nichols, C. (Producers), Books and Arts. Sydney, Australia: Australian Broadcasting Corporation. Retrieved from https://www.abc.net.au/radionational/programs/archived/booksandarts/corporate-art-collections/6999032

${ }^{14}$ Davis, B. (2018). A Very Provocative Collection': How Art Addiction at Lehman Brothers Helped Spark the 2008 Financial Crisis. Retrieved from https://news.artnet.com/opinion/lehman-brothers-art-crisis-1352824

${ }^{15}$ Ibid.

${ }^{16}$ Ibid.
} 
or controversial. Stephen McCoubrey - curator at UBS - says that 'Art gives the business personality', and is capable of differentiating their offices from those of Credit Suisse or another competitor. ${ }^{17}$ Contemporary art in particular, he says, has the ability to communicate to clients that the company is 'dynamic and growing'. ${ }^{18}$ The cultural diversity of the contemporary artists represented in UBS' collection - from Yang Fudong, to Jean-Michel Basquiat, to Lucian Freud - helps cultivate a corporate brand of being forward-thinking, modern and adaptable. The increased presence of corporate curators has contributed to the purchase of 'young art' and works by 'emerging artists' - art collecting professionals do not have to rely on the established reputation of an artist and can use their collecting acumen to identify emerging artists whose reputation they can bolster. ${ }^{19}$ All of this is illustrative of the prominence of the concept of 'corporate culture'. By linking corporate image to emerging artists, an image of innovation and agility is fostered. ${ }^{20}$ In a survey of corporate collection managers in Germany, Austria and Switzerland, Behnke found that $52.4 \%$ of interviewees strongly agreed with the statement that an artwork must be innovative was a factor in choosing a new artwork for the collection. ${ }^{21}$ However, as Alter states, only a small fraction of art sold on the primary market (the first sale of an artwork, from a gallery or from an artist's studio) becomes valuable enough for resale on the secondary market, ${ }^{22}$ increasing the risk of purchasing the work of emerging artists in the primary market.

But not all art is permanently in the possession of corporations. There is a burgeoning market for art rental. A range of business models have been deployed. They can vary in scale, from firms such as Artemus which trade in Matisse, Basquiat and the like, to more accessible businesses such as Ginger White which leases art to businesses for as little as $£ 1.50$ a week for some pieces. ${ }^{23}$ Some are essentially high-end rent-to-buy schemes, such as the services offered by Fellini Gallery in Berlin, which allows clients to convert rental fees into credit. ${ }^{24}$ Some are more artistfriendly - ArtMgt in New York shares leasing revenue with artists. ${ }^{25}$ The art rental market reflects diverse business models and these differences can have different impacts for the factors which may be at the forefront of a director's mind: being known as an artist-friendly firm could have better implications for corporate social responsibility, the ability to credit rental payments towards purchase of the painting could be more justifiable from an investment perspective than just renting the piece, owning works may cast the company as a 'custodian' rather than mercenary which has better public relations implications, but the opportunity to cycle through varied pieces over time could make for a more dynamic office environment for employees.

This barely scratches the surface of the corporate art collecting world (and penetrates even less of the murky and confusing art market as a whole) but provides a survey of the aspects of corporate collecting which will be discussed in relation to directors' duties in this article.

\section{Directors' Duties}

Although clearly there are many benefits to just 'having art around' - aesthetic concerns being the most obvious this does not remove the obligation of a corporation to act in accordance with directors' duties.

Two duties of directors and officers of corporations are of relevance to the issue of corporate art collecting: the duty to act in the best interests of the company, and the duty to exercise powers for a proper purpose. In Australia, these duties have long existed under the common law, and are also found in statutory form in s 181 of the Corporations Act 2001 (Cth). Section 185 of the Act states that the statutory duties act in addition to the common law, and therefore the common law cases continue to guide the courts in interpreting the statutory duties.

As formulated in Re Smith and Fawcett Ltd, ${ }^{26}$ adherence to the duty to act in the best interests of the company required only that the directors act bona fide in what they (subjectively) considered to be in the best interests of the company. This made breaches of the duty difficult to prove. However, the test has never been wholly subjective:

\footnotetext{
17 Above $n 4$.

${ }^{18}$ Ibid.

${ }^{19}$ Behnke, above n 5, 232.

${ }^{20}$ Ibid, 235.

${ }^{21}$ Ibid 237.

${ }^{22}$ Alter, D. (2009). Corporate art collecting and fiduciary duties to shareholders: Legal duties and best practices for directors and officers. Columbia Business Law Review, 2009, 1-66, 24.

${ }^{23}$ Harris, G. (13 June 2015). Something borrowed. The Financial Times, p. 7.

${ }^{24}$ Ibid.

${ }^{25}$ Ibid.

${ }^{26}$ [1942] Ch 304
} 


\section{In Hutton $v$ West Cork Railway $\mathrm{Co}^{27}$ Bowen LJ held that}

Bona fides cannot be the sole test, otherwise you might have a lunatic conducting the affairs of a company, and paying away its money with both hands in a manner perfectly bona fide yet perfectly irrational.

The law has now developed in a direction which emphasises the objective element and thus imposes a far more stringent standard on corporate officers. In ASIC $v$ Adler $^{28}$ the court held that the duty to act in the best interests of a corporation should be tested objectively, and will be breached if no reasonable director could believe that the conduct in question was in the best interests of the corporation. This means that to comply with the duty, a director must both honestly believe that the exercise of power is in the best interests of the company and the exercise would be considered to be in the best interests of the company by a reasonable director. ${ }^{29}$ However, although there could obviously be circumstances in which a director may honestly, yet unreasonably, believe that an exercise of power is in the best interests of the company and the duty will therefore have been broken, it is difficult to imagine circumstances in which an exercise of the power will be objectively reasonable and yet be one which the director subjectively did not believed to be in the best interests of the company. In other words, for all intents and purposes, the subjective test has now become conflated with the objective test. ${ }^{30}$

The leading case on the duty to exercise powers for a proper purpose is Howard Smith Ltd v Ampol Petroleum $L t d,^{31}$ in which the court held that in determining whether the duty had been breached, it was necessary first to determine the purpose of the power (that is, why the power exists) and then to determine whether the power had been exercised for that proper purpose. Most of the case law in this area of the law involved challenges to the issue of shares where directors have issued shares in order to serve their own personal interests (or those of their friends) in retaining control over a company. ${ }^{32}$ However, whereas the where the purpose of the power to issue shares namely capital raising - is easy to discern, directors and their delegates exercise a wide range of powers which are so general in nature as to not have one specific purpose. The general power to expend of corporate funds is an example of this.

For this reason, the courts have adopted a broad approach to defining what the purpose of the general powers of directors is. The rule formulated in Hutton $v$ West Cork Railway $\mathrm{Co}^{33}$ is that the directors breach the proper purpose rule if they use a company's powers for any purpose other than the 'benefit of the company.' In Hutton, addressing the question of whether directors could properly use company funds for charitable purposes, Bowen LJ held ${ }^{34}$ that

The law does not say that there are to be no cakes and ale, but that there are to be no cakes and ale except such as are required for the benefit of the company...It is not charity sitting at the board of directors, because as it seems to me charity has no business to sit at boards of directors qua charity. There is, however, a kind of charitable dealing which is for the interest of those who practise it, and to that extent and in that garb (I admit not a very philanthropic garb) charity may sit at a board, but for no other purpose.

The test in Hutton was affirmed in several other cases. ${ }^{35}$ The 'benefit of the company' test is obviously very broad. In Part 4 we discuss the various ways in which expenditure on the arts may considered to be for the benefit of a corporation.

It is also important to note that circumstances may arise in which a power is exercised for more than one purpose, one proper and the other improper. In that circumstance, the courts will determine whether the proper purpose rule has been breached by applying the 'but for' test, formulated in Whitehouse $v$ Carlton Hotel Pty Ltd. ${ }^{36}$ This test involves asking the question of whether, assuming the improper purpose had not existed, the corporate power would still have been exercised in the way that it was. If the power would still have been exercised even in the absence of the improper purpose, then the duty has not been breached. But if satisfaction of the improper purpose

\footnotetext{
27 (1883) 23 Ch D 654 at 671.

${ }^{28}$ [2002] NSWSC 171.

${ }^{29}$ Harris, J., Hargovan, A and Adams, M. (2018). Australian Corporate Law (6 ${ }^{\text {th }}$ ed,). Chatswood: Lexis-Nexis, 451.

${ }^{30}$ See ASIC v Adler [2002] NSWSC 171, Santow J at whether a director has acted for a proper purpose, namely for the benefit of the company, is to be objectively determined

31 [1974] AC 821.

${ }^{32}$ See for example Ngurli Ltd v MCCann (1953) 90 CLR 425, Howard Smith Ltd v Ampol Petroleum Ltd [1974] AC 821 and Whitehouse v Carlton Hotel Pty Ltd (1987) 70 ALR 251.

33 (1883) 23 Ch D 654.

${ }^{34}$ At 673.

${ }^{35}$ See for example Re George Newman \& Co [1895] 1 Ch D 674.

36 (1987) 162 CLR 285.
} 
was determinative of the power being exercised, the duty has been breached. ${ }^{37}$ The importance of this type of analysis in the context of corporate art purchases is illustrated by a statement made by Liz Christensen, a curator at Deutsche Bank, who said 'We're not buying for investment. But we're not buying not for investment, ${ }^{38}$ indicating that while investment was not the Bank's top priority, the value of works was a major consideration and so the purchases would have been made even in the absence of motivations other than that related to investment.

There is clearly an overlap between the duty to act in the best interests of the company and the duty to exercise powers for a proper purpose, because an exercise of power which is contrary to the best interests of the corporation will also amount to an exercise of power for an improper purpose. Furthermore, as stated above, the general rule enunciated in Hutton is that whether a power is exercised for a proper purpose depends on whether the power is exercised for the benefit of - in other words in the interests of - the company.

Although corporate art collecting most usually raises questions pertaining to the duties to act in the best interests of a corporation and to use powers for a proper purpose, corporate officers also need to be mindful of potential breaches of their fiduciary duty. Such breaches could take the form of making a profit as a result of being a director $^{39}$ or of the director putting herself in a position where there is a conflict between the interests of the corporation and her own personal interests. ${ }^{40}$ These common law duties are reflected in the Act, which prohibits improper use of position by a corporate officer (s 182) and misuse of information gained as a result of being an officer of a corporation (s 183).

An example of how close ties between corporate officers, their corporate collections, their personal collections and museums and galleries can raise possible conflicts of interests is provided by the Enron collapse and the activities of its CFO, Andrew Fastow. Following the collapse - which led to a plunge in the value of employees' pensions the press zeroed in on the millions spent on the company's corporate art collection by Fastow and his wife, with advice from curators at Houston's Museum of Fine Arts and the Menil Collection. ${ }^{41}$ Alter queries whether the Fastows' personal art collecting which occurred contemporaneously with and Andrew Fastow's collecting on behalf of the company may have resulted in a breach of fiduciary duty. ${ }^{42}$ This could have arisen in several ways: The market effect of his collecting for Enron may have caused his personal collection to appreciate in value, which raises the question of whether the choices he made in relation to the corporate art collection amounted to making of a personal profit as a result of his position as an officer of the corporation. There may also have been a breach of his duty to avoid a conflict of interest, in that his selection of art for the corporate collection could have been affected by the prospect of those choices enhancing the value of his private collection. Furthermore, being in a position where he could choose whether to acquire works either for Enron or for himself would have exposed him to the temptation of making better choices for his own collection than for Enron's, which again would amount to a conflict of interest. Finally, the Fastows may have received discounted prices for personal purchases on the strength of Andrew Fastow's collecting on behalf of Enron, which again amounts to making a personal gain as a result of being an officer of the corporation, and would also have amounted to a breach of the duty to avoid a conflict of interest because it raised the possibility that he might have paid more for works purchased on behalf of the corporation in exchange for discounts when purchasing for his own collection. ${ }^{43}$

\section{Corporate Art Collecting and Directors' Duties}

In light of the law analysed in Part 3, how should one determine whether use of corporate funds for the purposes of art collecting is consistent with directors' duties?

Taking the rule formulated in Hutton as our starting point, it is important to note the breadth of the test formulated in that case: Referring to the specific circumstance of a company making a charitable donation, Bowen LJ did not state that charitable donations are proper only if made for the 'financial benefit' of the company, only that they must be for the 'benefit' of the company - in other words, that the benefit that can accrue to a company may be something other than that which is measurable in monetary terms. Therefore, it is useful, in determining whether use of corporate funds for art collecting is or is not consistent with the proper purpose rule, to analyse the various

\footnotetext{
37 The but for test was also applied in Darvall v North Sydney Brick \& Tile Co Ltd (1988) 14 ACLR 474.

38 Sharf, S. (2 August 2012). The Top Art Collections. Forbes. Retrieved from https://www.forbes.com/sites/samanthasharf/2012/08/02/jpmorgan-ubs-and-other-big-banks-boast-top-corporate-artcollections/\#1ebbd0dc2684

39 See for example Regal Hastings Ltd v Gulliver [1942] 1 All ER 378.

40 See for example Furs Ltd $v$ Tomkies (1936) 54 CLR 583.

${ }^{41}$ Ebony, D. (2002). Enron Collapse impacts Art World. Art in America, 90, 35-7.

42 Alter, above $\mathrm{n} 22,4$.

${ }^{43}$ Ibid.
} 
interests of the corporation which may be served by expenditure on the arts.

The interests of the modern corporation are multifarious - they can be commercial, political or reputational. ${ }^{44}$ Furthermore, these interests are not separate - they are intertwined and each may impact on the others: For example, adverse political change can have a significant effect on a corporation's commercial well-being - an obvious example of this is provided by legislation enacted in many jurisdictions restricting the sake of tobacco. Harm to reputation can have negative effects on a corporation's performance. An example of this is provided by the repercussions of the 2010 oil spill at the Deepwater Horizon rig, owned by BP. In the months following the spill, BP petrol stations in the United States suffered drops of between 10 and $40 \%$ in fuel sales due to public backlash against the environmental harm the corporation had caused ${ }^{45}$ A corporation's political connections can affect its reputation, as shown by calls by consumers to boycott the In-N-Out fast food chain because of its donations to the Republican party in the United States in 2018. ${ }^{46}$ Thus, it is not only permissible, but we would argue necessary, for directors to take such interests into account when making decisions about corporate operations.

How does the expenditure of corporate funds on art impact on these interests? In what circumstances will such expenditure be held to be rationally connected to a corporate interest and, by contrast, in what circumstances will the link be so tenuous as to not be justifiable as an exercise of powers for the purpose of furthering the interests of the corporation? Although line-drawing may be difficult, the fact that, as was demonstrated in Part 2, corporations are spending increasing amounts on art, makes it necessary to identify some point at which such expenditure crosses the line between permissible deployment of shareholder funds in furtherance of corporate interests and an impermissible exercise of directorial self-indulgence. In answering this question, it is useful to examine those corporate interests which might be served by expenditure on the corporate art collecting.

\subsection{Expenditure on Artworks as an Investment}

First, and most obviously, the acquisition of artworks for investment purposes will prima facie satisfy the best interest test in so far as a corporation will reap direct financial benefit as the art it has purchased appreciates in value. Furthermore, although investing in artworks will often - indeed usually - fall outside the line of business of the corporation, we would argue that, in light of the breadth of the test in Hutton, such purchases would also be consistent with the duty to exercise powers for a proper purpose.

Buying art for corporations may be seen as a vanity, or an 'investment' merely in corporate image through conspicuous consumption: Andy Warhol once said 'Say you were going to buy a $\$ 200,000$ painting. I think you should take that money, tie it up, and hang it on the wall. Then when someone visited you, the first thing they would see is money on the wall. ${ }^{17}$ However, Behnke posits that the crash of the art market in the 1990s, followed by the steep growth of the market and increasing popularity of art fairs, legitimised corporate art collecting through the 'logic of the art market' ${ }^{48}$ Legitimised as it may be, is art collecting actually a reasonable form of investment for corporations?

Economist Don Thompson suggests to readers of his book The $\$ 12$ million stuffed shark that they ask themselves whether each art purchase mentioned "seems to you a decent investment. Not just 'Will this art be important twenty-five years from now?' but 'Will this art double in value in ten years as would a moderate risk bond portfolio?' For almost all art, the answer is no." ${ }^{49}$ The Sotheby's Mei Moses index - which uses repeat sales of the same art objects from different points in time to track changes in value ${ }^{50}-$ showed that art assets tend to suffer from higher volatility and lower liquidity than the stock market, ${ }^{51}$ but due to their lack of correlation with other asset classes, can serve as a good vehicle for portfolio diversification. ${ }^{52}$ Nevertheless, a study by academics at Tilburg University and HEC Paris which reviewed 1.2 million auction house sales found an appreciation of $3.97 \%$

\footnotetext{
${ }^{44}$ See Klein, E. and du Plessis, J. (2005). Corporate Donations, the Best Interests of the Company and the Proper Purpose Doctrine. University of New South Wales Law Journal, 28, 69-97.

45 Weber, H. (30 July 2010). Time to scrap BP brand? Gas-station owners divided. NBC News. Retrieved from http://www.nbcnews.com/id/38493212/ns/business-us_business/t/time-scrap-bp-brand-gas-station-owners-divided/\#.W44N_c4zbDc

46 Tsang, A. (31 August 2018). In-N-Out's Political Donation Attracts Boycott Calls, but Will It Matter?. The New York Times. Retrieved from https://www.nytimes.com/2018/08/31/business/in-n-out-burgers-boycott-california-republicans.html

47 Thompson, above n 6, 202.

${ }^{48}$ Behnke, above n 5, 227

49 Thompson, above n 6, 26.

50 Sotheby's. (26 October 2016). Sotheby's Acquires the Mei Moses Art Indices. Retrieved from https://www.sothebys.com/en/articles/sothebys-acquires-the-mei-moses-art-indices

${ }^{51}$ Alter, above n 22, 21.

52 Ibid.
} 
per year between 1957 and $2007 .{ }^{53}$ This is a modest return, but comparable to the return one might expect on a long term deposit at a bank. Financial advisors agree: Chase de Vere does not generally recommend investing in art, as, 'there are big movements upwards or downwards if there are changes in the economic environment or if particular works or artists come in or out of fashion' ${ }^{54}$ The firm does however make an exception to this advice where a person or company already has a broad and extensive portfolio, in which case (again) art can assist with diversification. ${ }^{55}$

Another important factor to consider when comparing art to other forms of investment is the 'holding period effect': A study of the Sotheby's Mei Moses indices suggested that collectors who held their art purchases for at least ten years were less likely to lose money on their investment than those collectors who only held the work for three years ${ }^{56}$ For contemporary works, $88 \%$ of pieces held for at least a decade sold for more than their purchase price, as compared to only $65 \%$ of works held for three years or less. ${ }^{57}$ This is not likely to be a big issue for corporations who are forming a corporate collection which serves to express the 'personality' of the company, rather than trying to flip works at auction to make money quickly. It is however an important timeframe to take into account in justifying collecting policies on investment grounds.

As a final consideration on the point of expected returns and growth, the demands of investment might be quite different to the demands of a collecting policy based on aesthetics or on corporate social responsibility considerations. Consider this: The artnet Index for the Top 100 Artists produced an $8 \%$ compound annual growth rate $(\mathrm{CAGR})^{58}$ for the period between 2000 and 2018. The S\&P 500's CAGR was $3 \%$ over the same period. However, when this is broken down to categories of art on the market, the results are very different. Over the last five years, the European Old Masters market had a CAGR of $-2.82 \%$, Global Impressionist Art, $-3.92 \%$, and Global Modern Art, $2.87 \%$. Luckily for companies, who often collect the art of emerging artists to support their corporate social responsibility goals, Global Contemporary Art had a CAGR of $5.70 \%{ }^{59}$ This snapshot suggests it may be easier for a start-up buying contemporary art to justify its collecting from an investment perspective, than for an old-school corporate collector that has an eye for Impressionist works. But then again, because European Old Masters and Global Impressionist Art show a lower correlation with the S\&P 500 than Global Contemporary Art, ${ }^{60}$ they could be a better vehicle for diversification. The subtleties of art as an investment vehicle illustrate not only that it may be difficult to consistently justify particular collecting policies from an investment perspective, but that directors without experience in the art market may lack the nous to make collecting decisions.

Even if one accepts that a particular work or purchasing programme is a good financial investment, owning art can be expensive in itself. The costs of obtaining the services of a professional curator or advisor, the cost of protecting art (including transportation and monitoring humidity, temperature and light levels), and insurance can all be financial drains. These costs will generally be higher where works are put on public display (which is generally the intended purpose for works purchased for corporate collections). Additionally, the market is broadly unregulated, and provides little protection against fraud: $84 \%$ of wealth managers view issues around authenticity, provenance and forgery as the greatest area of risk in the art market. ${ }^{61}$ A company may always know if its ASX listed stocks are blue chip stocks or not, but you may never be sure your Giacometti is the real deal. ${ }^{62}$ All this serves to say that art investment can be a risky business. Indeed, the $6^{\text {th }}$ edition of the Deloitte Art \& Finance Report (2019) found that the perception of risk in the market was heightened since the publication of the $5^{\text {th }}$ edition in 2017.63 Perception of risk in itself can, of course, make for an unsteady market.

\footnotetext{
${ }^{33}$ Renneboog, L. and Spaenjers, C. (2013). Buying Beauty: On Prices and Returns in the Art Market. Management Science, 59, 36-53.

${ }^{54}$ Hope, K. (16 November 2017). Could buying paintings make you rich? BBC News. Retrieved from https://www.bbc.com/news/business42011989

${ }^{55}$ Ibid.

56 Deloitte Luxembourg. (2019). Art \& Finance Report $\left(6^{\text {th }}\right.$ ed). $141 . \quad$ Retrieved from https://www2.deloitte.com/content/dam/Deloitte/lu/Documents/financial-services/artandfinance/lu-art-and-finance-report-2019.pdf ${ }^{57}$ Ibid.

${ }^{58}$ Ibid 129

${ }^{59}$ Ibid 135

${ }^{60}$ Ibid 126.

${ }^{61}$ Ibid 202.

${ }^{62}$ Cascone, S. (17 October 2016). 9 of the Craziest Recent Art Forgery Scandals. Artnet news. Retrieved from https://news.artnet.com/artworld/recent-art-forgery-scandals-705428

${ }^{63}$ Above n 55.
} 
But is making 'smart' purchases enough? The fact that a piece of art purchased may have a good resale value may not be enough to satisfy the requirements of corporations law: Conceivably, the point could be reached at which the board was allocating so much of the corporation's resources to the acquisition of artworks that shareholders could bring an action for compulsory winding up on just and equitable grounds under s 461(1)(k) of the Corporations Act 2001 (Cth), following the precedent of Re Tivoli Freeholds Ltd, ${ }^{64}$ where the court held that 'failure of the substratum' - that is a change in the corporation's business to one not reasonably within the contemplation of the shareholders - would amount to just and equitable grounds for winding up. However, it should be noted that Tivoli is the only reported case in which winding up has been granted on the basis of failure of the substratum, and it is therefore reasonable to think that it would be only in the most extreme cases of re-deployment of corporate resources that that would occur. One can therefore assume that directors of a corporation the core business of which was not art investment would be safe in including art among the corporation's investment portfolio - as is indeed illustrated by the example of Deutsche Bank discussed in Part 2, which has art holdings consisting of 57000 pieces.

In the same vein one should also mention the equal unlikelihood that shareholders who were dissatisfied with corporate expenditure on artworks would succeed in arguing that that course of action was contrary to the interests of the members as a whole or oppressive or unfairly prejudicial or discriminatory against members under s 232 of the Act. In Wayde v New South Wales Rugby League, ${ }^{65}$ the High Court held that the s 232 action for oppression cannot be used to resolve disputes between groups of shareholders over business decisions by a corporation, and that as long as the conduct of the board is such that a reasonable board might engage in, no oppression will be found to have occurred. The use of corporate funds to invest in artworks would surely satisfy the test of reasonableness unless, for example, the level of expenditure relative to the assets of the company was so large as to take it outside the realms of what a reasonable board might do. ${ }^{66}$

\subsection{Corporate Social Responsibility}

The corporate social responsibility movement, which has become increasingly prominent, promotes the idea that corporations have a moral obligation to consider the effect of their actions on society as a whole and to engage in, and contribute to, socially beneficial initiatives. In the same survey of Swiss, Austrian and German corporate art collectors mentioned in Part 2 above, $47.6 \%$ of respondents strongly agreed with the statement that corporate social responsibility was a factor in the foundation of a corporate collection. ${ }^{67}$

There are many examples of how corporations satisfy the demands of corporate social responsibility by spending money in support of the arts. UBS is the principal sponsor of the annual Art Basel fair. The fair's importance is apparently so high to the Swiss bank that it is the only sponsorship event that does not have to be approved at board-committee level. ${ }^{68}$ UBS's success in using Art Basel to tempt wealthy potential clients has been so great that HSBC hosts a refreshment tent near the event. Deutsche Bank has sponsored other art fairs such as Frieze. ${ }^{69}$ Less dubious, perhaps, than sponsorship of art fairs (which are primarily fora for wealthy collectors to purchase art) are the display of works from corporate collections at public galleries. UBS has a strong history of partnering with art museums internationally, as exemplified by the UBS Openings exhibition series at the Tate Modern. ${ }^{70}$ Such partnerships, making public company owned works which are not often seen by the general public, are undoubtedly a contribution to broader cultural life.

The Wesfarmers Collection of Australian Art has 900 works in its collection, 800 of which are in its premises and 100 of which are on tour or in galleries. ${ }^{71}$ A 'de facto' gallery is located on the executive floor of the main corporate premises, and is used for public engagement and events. ${ }^{72}$ Helen Carroll - the curator of the collection expressing the intersection between corporate social responsibility and investment considerations, said that the Collection is an investment from the perspective of the shareholders, and that it is 'not an investment [Wesfarmers] look[s] at in purely financial terms, it's a longstanding investment'. The managing director of the company in the

${ }^{64}$ [1972] VR 445.

${ }^{65}$ (1985) 180 CLR 459.

${ }^{66}$ Klein and du Plessis, above n 44, 91.

${ }^{67}$ Behnke, above n 19, 237.

${ }^{68}$ Thompson, above n 6, 192.

${ }^{69}$ Ibid.

${ }^{70}$ Tate Modern. (2006). Tate Modern opens first major rehang of its Collection with the support of UBS. Retrieved from

https://www.tate.org.uk/press/press-releases/tate-modern-opens-first-major-rehang-its-collection-support-ubs

71 Above $n 13$.

${ }^{72}$ Ibid. 
mid-1980s (when questions arose as to whether the collection should be seen as investment or sold) Trevor Eastwood said of the works that '[y]ou either sell them because you shouldn't have paintings, or if you should have paintings you buy more"73 - this attitude continues today with Carroll saying the company doesn't 'sell for investment purposes' and instead focusses on supporting the work of living artists. ${ }^{74}$ The rewards of engagement with the community and supporting the artistic sphere may not be high in financial terms and it must be recognised that the corporate social responsibility benefits of a collecting programme can only be realised over the long term.

Demonstration by companies of a commitment to corporate social responsibility has a positive effect on their public reputation of a corporation - and public reputation is a legitimate corporate interest. The scope of activities which could be considered to be of benefit to society is very broad and therefore, in so far as art is generally considered a social good, support for any type of artistic activity would appear to be a manifestation of corporate social responsibility, and thus a legitimate allocation of corporate resources which is consistent with directors' duties. However, is this to take matters too far, given that on this reasoning, any and every corporate expenditure on art would appear to be legitimate? Does the underlying hypothesis that all art is a social good, support all corporate expenditure on the arts? Or is something more required other than support for the mere engagement in artistic activity?

This is a profound question to which the artist and the corporate lawyer might give different answers. From an art theory perspective, one could say that any artistic activity - even, for example, a novel written but never published, or a painting that remains hidden in the artist's studio and seen by no-one but him or her self - is indeed a social good in that it adds to the artistic legacy of humankind. However, from the perspective of a lawyer determining whether corporate support for an activity amounts to a social good for the purposes of manifesting corporate social responsibility, it could be argued that something more than the mere production of art is required. After all, the concept of a social good implies social impact with a degree of immediacy that is missing in the case of the hidden novel or painting. Therefore, we would argue that support for artistic endeavour is not in itself sufficient to amount to engagement in corporate social responsibility. For corporate expenditure to be considered an act of corporate responsibility - and thus within the duty to exercise powers for a proper purpose - it must relate to artistic endeavours which have an immediate impact, and that impact must extend beyond the artist him or herself. An example of an art acquisition policy that accords with this is provided by Stephen McCoubrey, the curator in charge of the UBS art collection, whose approach to acquisitions focusses on purchasing new art, rather than the secondary market and auctions; he says the purpose of this is to benefit artists, rather than monolithic auction houses. ${ }^{75}$

Thus, the degree to which there is public exposure of art supported by a corporation will be an important factor in determining whether the expenditure benefits a corporation from a reputational point of view. To take contrasting examples, while corporate sponsorship of a public display of art works would clearly be justifiable as expenditure enhancing reputation, the purchase of a painting to hang in the office of the chief executive officer would confer a far narrower reputational benefit which arguably is not sufficient to justify expenditure of corporate funds, even if it became known that the corporation was supporting the artist. Nuances lie in where and how art is displayed (if at all) by corporations. Far from being in the office of the CEO, for example, Deutsche Bank and the Solomon R. Guggenheim Foundation established the Deutsche Guggenheim Berlin in 1997. During operation (the exhibition space closed in 2013), the Deutsche Guggenheim held three to four exhibitions a year, often displaying works specially commissioned. ${ }^{76}$ Such ventures allow a corporation to garner media attention, while (particularly when works are specially commissioned), supporting emerging artists.

Finally, even accepting that engaging in philanthropy can be in the best interests of a corporation, such activity has its limits: One could question whether the board of directors of ING could be said to be acting in the best interests of the company when, following the Global Financial Crisis, having divested its insurance business, it found it had less space for art display. Its art collection shrank from 25000 to 10000 pieces - some of these were donated to the Rijksmuseum. ${ }^{77}$ Philanthropic as this may be, it is difficult to see whether, having spent company funds on the purchase of these pieces, and being in a period of downturn, it was in the best interests of the company to donate

\footnotetext{
${ }^{73}$ Wesfarmers Limited. (2020). The start of the Wesfarmers art collection. Retrieved from https://www.wesfarmers.com.au/who-we-are/ourhistory/the-start-of-the-wesfarmers-art-collection

74 Above n 13.

75 Above $n$.

76 Solomon R. Guggenheim Foundation. (2020). Collection on Deutsche Guggenheim Berlin. Retrieved from https://www.guggenheim.org/finding-aids/collection/a0054

77 Karabell, S. (24 May 2016). How And Why You Should Start A Corporate Art Collection. Forbes. Retrieved from https://www.forbes.com/sites/shelliekarabel1/2016/05/24/how-why-to-start-a-corporate-art-collection/\#7flea5587124
} 
them to the museum.

\subsection{Psychological Benefits}

It is well-established that a corporation may act in the best interests of its employees to the extent that that is to the benefit of the corporation. ${ }^{78}$ An important benefit that may accrue from corporate expenditure on the arts is the psychological benefit that employees derive from having artworks in the workplace. A congenial work environment leads to multiple benefits such as reduced employee stress, improved inter-personal relationships and reduced employee turn-over, all of which will promote increased productivity, which is of benefit to a corporation. A good example of this is provided by the Penguin Books' collection: Assembled for about $£ 200,000$, it consists of about 200 works and reflects the heritage and purpose of Penguin's business. Consisting nearly exclusively of limited-edition prints by British artists who work with text, ${ }^{79}$ the collection pays homage to the publishing house's work and history. Although the collection provides no apparent financial benefit to the company, it is a manifestation of corporate pride which, it could be argued, enhances employees' identification with, and loyalty to, the company, which would be likely to have a positive effect on productivity.

Exeter University's School of Psychology has found that people working in 'enriched' spaces, decorated with art or indoor plants, were $17 \%$ more productive than those working in bare and functional 'lean' spaces. ${ }^{80}$ Furthermore, a survey by the Business Committee for the Arts and the International Association for Professional Art Advisors found that having art in the workplace assists in addressing business challenges such as reducing stress $\left(78 \%\right.$ agreed) ${ }^{81}$ Enriching working environments may be considered even more important with the preeminence of 'open plan' offices. The perceived 'loss' of one's personal space or office to decorate can be ameliorated by the broader access of all staff to corporate collections. This may be even more important when a business moves premises, as the familiarity of art which was previously on display can increase a sense of belonging, or the display of new art from the collection may assist in giving the company a new 'face' for its employees.

Here again, the breadth of exposure of artworks will impact on the extent to which employees, and thus the corporation, derive a benefit: Whereas displays in public spaces, workplaces and recreation spaces would have clear psychological benefit for a range of employees, the sequestering of artworks in executive spaces would benefit a far smaller group of employees and would therefore be less easily justifiable. UBS' collecting practice illustrates well the two audiences corporate collections cater to: The Swiss Bank's collection is divided in two, with the most 'impressive' (read coveted, expensive) works are displayed in areas where they can be appreciated by clients, and lower value works put on the walls of offices around the world for the enjoyment of employees. ${ }^{82}$

Another factor to take into account in determining the psychological benefit of corporate art expenditure is the different benefit resulting from art which is hired as distinct from that which is purchased. There is an increasing trend towards art rental by corporations, which enables a changing collection of artworks to be rotated through the workplace, thereby allowing for both diversity and novelty in the range of artworks to which employees are exposed, which arguably provides greater psychological benefit than a purchased collection which changes far more slowly. A purchased collection may also have an underlying theme (such as Wesfarmers' focus on Australian art), which may or may not be conducive to a good working environment. That is, the works that a company collects for its purchased collection (which may be displayed in gallery spaces, on client floors, or loaned to museums) may be quite different from the kind of work its employees may want in their office space.

\section{Conclusion}

Compliance with directors' duties requires corporations to develop a reasoned strategic plan for art collecting. Such a plan would pre-emptively address shareholder questions regarding the justification for the collection. Of course, it is to be expected that the plan and the collection may change over time as works are acquired or deaccessioned in light of the goals of the collection. Each of the three rationales for corporate art collecting outlined in Part 4 (investment, corporate social responsibility and psychological benefits) are important and work together like aspects of a work of art themselves: corporate culture and psychological benefits may be the primer for the work, laying down a preliminary surface. The paint applied to the primed canvas may stand in for corporate social

\footnotetext{
${ }^{78}$ Parke v Daily News Ltd [1962] Ch 927.

${ }^{79}$ Above $\mathrm{n} 4$.

${ }^{80}$ Higginbottom, K. (23 September 2019). The Impact of Art in the Workplace. Corporate Artworks. Retrieved from https://corporateartworks.com/blog/f/the-impact-of-art-in-the-workplace

${ }^{81}$ Ibid.

82 Above $\mathrm{n} 4$
} 
responsibility and investment considerations, blended together as different hues, but harmonious nonetheless. Underlying all this is the canvas of a documented and considered corporate art collecting policy, and to the side of the finished work we might see the exegesis in the form of marketing and public relations considerations.

In light of the law discussed in this article, we would recommend that the following principles should lie at the foundation of a policy governing a corporate art collecting and sponsorship policy in order to ensure that the policy is consistent with directors' duties:

1) Corporate ventures into the art market should demonstrably serve the interests of the corporation, tested both subjectively and objectively.

2) It is permissible for corporate art collecting and sponsorship to serve more than one interest, including interests that are unrelated to the interests of the corporation, but in that event, it must still be the case that the corporation would have engaged in the activity even in the absence of those other interests.

3) The corporation has a responsibility to ensure that no conflict exists between the interests of the corporation and the private art-collecting activities of employees and officers involved in corporate art collecting.

4) Where art is acquired as an investment, it is prudent to obtain the services of a professional art consultant, art rental company, or dealer. It is unlikely that the average company officer will have the necessary acumen to assess the investment prospects of works. In such circumstances, it will also be prudent to consider the very different variables to which the art market is subject, as compared to the stock market. Such variables include fluctuating interest in an artist over time, trends in the art world as a whole, the practices of gallerists, auction houses and art museums, the scarcity or otherwise of an artist's work (and whether the artist is dead or alive, which is a related issue), and the whims of high profile figures in the market, to name a few.

5) Corporate art collecting should be limited to a scale relative to the business activities of the corporation and should not supplant the corporation's business activities.

6) Acquisitions should be reasonable in the sense of according with what decisions a reasonable board would take.

7) Acquisitions and sponsorship engaged in for the purposes of corporate social responsibility should yield an immediate benefit to society and should extend beyond benefitting the artist him or herself. This will especially be the case where works are acquired on the secondary market, and where the purchase may therefore have an even more limited benefit to the artist.

8) When collecting art for the purpose of enhancing the work environment, the guiding principle should be maximum exposure of art to visitors and employees and regular rotation. In such circumstances, the views of employees (who will view the art on a daily basis) and what may be accepted as generally aesthetically pleasing may legitimately take a higher priority than when art is collected for other purposes.

Art is a feast for the eyes (and, as we have seen, for reputation, an investment portfolio and productivity as well). So, we might say to company directors that their golden rule should be that it is not only cakes and ale which may be permissible when required for the benefit of the company, but Rothkos and Lichtensteins too.

\section{References}

Alter, D. (2009). Corporate art collecting and fiduciary duties to shareholders: Legal duties and best practices for directors and officers. Columbia Business Law Review, 1-66.

Behnke, C. (2007). Corporate Art Collecting: A Survey of German-Speaking Companies. The Journal of Arts Management, Law, and Society, 37, 225-244. https://doi.org/10.3200/JAML.37.3.225-244

Cascone, S. (17 October 2016). 9 of the Craziest Recent Art Forgery Scandals. Artnet news. Retrieved from https://news.artnet.com/art-world/recent-art-forgery-scandals-705428

Cathcart, M. (8 December 2015). Corporate Art Collections [Radio series broadcast]. In Barraud, A., \& Nichols, C. (Eds.), Books and Arts. Sydney, Australia: Australian Broadcasting Corporation. Retrieved from https://www.abc.net.au/radionational/programs/archived/booksandarts/corporate-art-collections/6999032

Davis, B. (2018). A Very Provocative Collection': How Art Addiction at Lehman Brothers Helped Spark the 2008 Financial Crisis. Retrieved from https://news.artnet.com/opinion/lehman-brothers-art-crisis-1352824

Deloitte Luxembourg. (2019). Art \& Finance Report (6th ed.). 141. Retrieved from https://www2.deloitte.com/content/dam/Deloitte/lu/Documents/financial-services/artandfinance/lu-art-andfinance-report-2019.pdf 
Ebony, D. (2002). Enron Collapse impacts Art World. Art in America, 90, 35-7

Harris, G. (13 June 2015). Something borrowed. The Financial Times, p. 7

Harris, J., Hargovan, A., \& Adams, M. (2018). Australian Corporate Law (6th ed.). Chatswood: Lexis-Nexis.

Higginbottom, K. (23 September 2019). The Impact of Art in the Workplace. Corporate Artworks. Retrieved from https://corporateartworks.com/blog/f/the-impact-of-art-in-the-workplace

Hope, K. (16 November 2017). Could buying paintings make you rich? BBC News. Retrieved from https://www.bbc.com/news/business-42011989

Jovic, M. (2018). Art Owned by Businesses: The Changing Role of Corporate Art Collections. Retrieved from https://medium.com/predict/art-owned-by-businesses-the-changing-role-of-corporate-art-collections$5292 \mathrm{e} 65 \mathrm{c} 9 \mathrm{~b} 17$

JPMorgan Chase \& Co. (2020). JPMorgan Chase Art Collection. Retrieved from https://www.jpmorganchase.com/corporate/About-JPMC/jpmorgan-art-collection.htm

Karabell, S. (24 May 2016). How and Why You Should Start A Corporate Art Collection. Forbes. Retrieved from https://www.forbes.com/sites/shelliekarabell/2016/05/24/how-why-to-start-a-corporate-artcollection/\#7flea5587124

Klein, E., \& du Plessis, J. (2005). Corporate Donations, the Best Interests of the Company and the Proper Purpose Doctrine. University of New South Wales Law Journal, 28, 69-97.

Macquarie Group Ltd. (2020). Macquarie Group Collection. Retrieved from https://www.macquarie.com/au/en/about/community/macquarie-group-collection.html

Renneboog, L., \& Spaenjers, C. (2013). Buying Beauty: On Prices and Returns in the Art Market. Management Science, 59, 36-53. https://doi.org/10.1287/mnsc.1120.1580

Sharf, S. (2 August 2012). The Top Art Collections. Forbes. Retrieved from https://www.forbes.com/sites/samanthasharf/2012/08/02/jpmorgan-ubs-and-other-big-banks-boast-topcorporate-art-collections/\#1 ebbd0dc2684

Solomon R. Guggenheim Foundation. (2020). Collection on Deutsche Guggenheim Berlin. Retrieved from https://www.guggenheim.org/finding-aids/collection/a0054

Sooke, A. (2014). Corporate Art Collections: The greatest art you can't see. Retrieved from http://www.bbc.com/culture/story/20140814-the-greatest-art-you-cant-see

Sotheby's. (26 October 2016). Sotheby's Acquires the Mei Moses Art Indices. Retrieved from https://www.sothebys.com/en/articles/sothebys-acquires-the-mei-moses-art-indices

Tate Modern. (2006). Tate Modern opens first major rehang of its Collection with the support of UBS. Retrieved from https://www.tate.org.uk/press/press-releases/tate-modern-opens-first-major-rehang-its-collectionsupport-ubs

Thompson, D. (2012). The \$12 Million Stuffed Shark: The Curious Economics of Contemporary Art. London: Quarto.

Tsang, A. (31 August 2018). In-N-Out's Political Donation Attracts Boycott Calls, but Will It Matter? The New York Times. Retrieved from https://www.nytimes.com/2018/08/31/business/in-n-out-burgers-boycottcalifornia-republicans.html

Weber, H. (30 July 2010). Time to scrap BP brand? Gas-station owners divided. NBC News. Retrieved from http://www.nbcnews.com/id/38493212/ns/business-us_business/t/time-scrap-bp-brand-gas-station-ownersdivided/\#.W44N_c4zbDc

Wesfarmers Limited. (2020). The start of the Wesfarmers art collection. Retrieved from https://www.wesfarmers.com.au/who-we-are/our-history/the-start-of-the-wesfarmers-art-collection

\section{Copyrights}

Copyright for this article is retained by the author(s), with first publication rights granted to the journal.

This is an open-access article distributed under the terms and conditions of the Creative Commons Attribution license (http://creativecommons.org/licenses/by/4.0/). 